\title{
Florescence of revolution in Shafaq's poetry
}

\author{
Seyed Mohammad Bagher Kamaladdini \\ Persian literature and language branch, Yazd Payam-e-Noor University \\ E-mail address: Kamaladdini@pnu.ac.ir
}

Keywords: poetry, spring, revolution, Shafaq, Yazd

\begin{abstract}
Blossoms of Persian poetry, although inspired by the pure nature, gradually took the attractive qualities of mysticism. In traditions, the Holy Quran is called the burgeoning of hearts and the greatest prophet (peace be upon him) is referred to as the burgeoning of souls. Spring in Persian literature is sometimes the symbol of improvement and deliverance and at other times is considered as the symbol of the afterlife. Actually, this is the highest symbol of spring in Persian literature.

Desert land of Yazd bears fragrant flowers, in spite of its natural wrath, tickles the taste of souls of the pious people. One of these scented flowers is the deceased Behjati whose pen name is "Shafaq" and spring in his poetry possessed the qualities of revolution. Current study is going to address this concept in his poetry.

The article was conducted with an analytical-descriptive method using bibliographic resources.
\end{abstract}

\section{INTRODUCTION}

Poets and writers are among the greatest divine blessings having the largest contribution in development of societies. Their works illuminate human ways of life over different ages.

Its name is omitted from writing in the notebook of the ages among illiterate nations

Spring is viewed from two aspects in Persian literature:

(Farokhi Yazdi, 2003, 45)

First, from poetical visualizations which can be seen in Khorasani poetical style and pioneers in Persian poetry have offered masterpieces to this respect for all those interested. It is worthy of explanation that during $4^{\text {th }}$ and $5^{\text {th }}$ centuries, poetry in our classical literature had a horizontal approach typically describing tangible and visible phenomena, as the master of poets and the father of Persian poetry stated:

The fresh spring has come with its sweet attractive quality and flavor

With thousands of pleasure and purity and strange decoration

The great fate is the commander

Its army is the dark cloud its leader is zephyr

Its fireman is the flash of lighting and its thunder is its drummer

I saw lots of troops but not so horrible and dreadful

(Nafisi, 1962, 492)

In this spring ode, the poet accompanies description of spring with wonderful similes and visualizations. Darks clouds as the troops, zephyr as the leader of this army, the lightning as the fireman of these people and then goes on to describe tulips:

The tulip is smiling within the plain from a far distance

As if the bride's hands are covered with henna

(The same source, the same page)

In this regard, it is worthy to refer to spring poetries with the same features by Manouchehri Damghani:

The spring has come with flowers and jasmines

The garden is like Tibet and the meadow like the Eden

The sky pitched a tent out of the dark flag and soft silk

Its pins are the roots of jasmines and sweetbriers

(Manouchehri Damghanim, 1984, 1) 
Manouchehri's art in visualization is that he persuades the addressee to see the nature from a different point of view and says: as if the sky is a tent made up of soft and dark tissue and Jasmine and sweetbriers are pins of this tent. Then, he likens the garden to a colorful idle-temple and says:

As if the garden is a decorative idle-temple

Birdies like jasmines and rosebushes like idols

Jasmine kisses the sole and body of idols

When is the idol going to kiss the sole of Jasmine

(The same source and page)

However, the second approach, beginning over the next centuries, i.e. from the $6^{\text {th }}$ century with the advent of mysticism in Persian poetry, is a sensual one. In such works, the concept of spring is concomitant with human sensual transformation and poets consider it a pretext for inner revolution:

A stone never gets fresh and green during the spring

Be as soil to grow colorful flowers

You have been a rigid stone for years

Try once to be like soil

(Molavi, 1986, first volume, 116)

In other words, spring in Iraqi style poetry is not the spring of nature but it is the symbol of improvement and relief after human inner revolution and difficulty and revival in the afterlife. As Molavi quotes:

This new and fresh spring after the resurrection

Is the reason for the existence of the afterlife

(Molvai, 1986, fifth volume, 252)

However, sometimes the spring is likened to human life for its transience and short life, particularly during youth times, and the poet advises us to perceive the spring of young times which is ephemeral:

The flower is welcomed and nothing is more pleasant

When nothing is in your hand but the goblet

Make the most of your chances and drink wine in the garden

As the flower is not surviving until the next week

(Hafiz, 2007, ode 162)

Nowrooz and spring poetry in Persian literature as other topics are typically replete with Quran allusions and hints.Quran is entitled the spring of hearts in traditions and the profit is referred to as the spring of souls.

Spring in Persian literature is sometimes the symbol of improvement and relief after pains and difficulties and sometimes the symbol of the afterlife and this is the most sublime symbol for spring in Persian poetry.

Saadi, combining intellectual concepts with the description of nature, praises the spring and reflects both the inner aspects of mind and outer perspectives of the universe. He praises the endless generosity of spring clouds in Golestan which is among the best examples of spring description. A century after Saadi, Hafiz with a mystical perspective and some sparks of Khayyam's ideas portrays the flowers growing from nonexistence during spring.

Spring in the poetry of Yazd poets

Although Yazd is considered an area with a small number of poets in Iran due to its unfavorable natural conditions, if we refer to historical books and biographies of poets, we will find out that this land as other areas in our country has had great poets, wise men and scientists, each as one of our national glories.

Spring is widely reflected in the poetry of Yazd poets including Vahshi, Taraz, Jeyhoon, Ghazayi and etc.

One of poets from this land who refers to spring in his poem is the deceased Mohammad Hosein Behjati whose pen name is "Shafaq".

My mistress who smells as the spring wind

It is so pleasant to visit the garden 
Watch the beauty of God in the mirror of the garden

Taking over the paradise in ravishing hearts

My flower creator! Thou the high jovial one

Look at the happy trees in Tabriz

Seehow they sing as the breeze blows

As the string of the tar making sounds with a blazing plectrum

Thou are that breeze and I am that murmuring tree

I am drowned with the ominous song as thou rise

(Shafaq, 1994, 195)

Ayatollah Mohammad Hosein Behjati (Shafaq) was born in Ardakan in 1934. In his 12, he studied religious science at Ardakan religious school enjoying the presence of masters such as Haj Molla Mohammad Haeri, their eminence Khatami and Olumi until 1952 in Ardakan and Yazd. In 1952, he set out for Qom and continued his education in Khan School.

Then he learned higher education courses in company with great masters such as Imam Musa Sadr, Ayatollah Shobeiri Zanjani, Fakur, Haj Morteza Haeri and Imam Khomeini followed by courses of jurisprudence and Islamic principles in presence of educators such as Ayatollah Boroujerdi and Imam Khomeini.

Master Behjati, from his young age, versified some pleasant and sweet verses, many times appraised by his friends. In 1959, at a literary meeting he got acquainted with Ayatollah Khamenei while reading an ode from his own verses after which they had a warm friendliness. In the beginning of Islamic movement led by Imam Khomeini in 1962, he wrote his first poem about Islamic revolution and read it in presence of Imam Khomeini who praised him a lot. As such, he is well-known as the poet of the first revolution-related poem. Shafaq was a literary clergyman who spent some time for poetry, mysticism and literature along with other daily political and social activities and enjoyed the works of other great Persian literary men, the consequence of which are several published poetical books, and the pick of the basket is his odes....

In an ode titled "the first spring of freedom" portrays the spring of revolution in poetry:

This spring is more beautiful than any other spring

Our land was more dehiscent than the paradise

Jasmine and lily are no more silent

And every flower says more than hundreds of verses

The nature is younger and the flower is more fragrant than this uprising which won

For people's zeal of relief the breeze was more free and the time more dynamic

Tell the cedar to erect to watch that tulip is more reddish and the grass more charming

From the waves of the martyrs' blood

This revolution constantly gets more beautiful

The tulips growing on the soil of martyrs

The flower garden becomes happier and tomorrow will be more cheerful

It is early morning, stay to see

Because this sun gets more shining every moment

As the Muslim people are aware and fighters

This uprising is greater than any revolution

It has always been the tradition in the world

That God helps the more diligent people

Don't forget the role of the leader here

Who is the wisest and clear-sighted

If the speech is going to convey a message

God's revelation is more eloquent than any word

The message of freedom comes out of Shafaq's song

It is more budding than flower and more euphonious than flute 
In this poem, the poet describes the spring and mentions spring words and beautifully reminds that the spring of freedom makes this season more cheerful and charming. In another poem, Shafaq portrays the beauty of spring to attract the reader's attention to the beauty creator, God.

You said that the garden is soaked into fresh flowers

Blossoms have created the paradise

As if the bud has made a morning drought out of cloud glass

It is drunk disclosing its face

You said the garden is full of flower fragrance

Dew is leaking coquettishly on the flowers

You said the zephyr,like Zoleikha, keenly

Has torn out Joseph's gown from behind

You said the delicate spring is spectacular

Whoever seeing it, is attracted to it

As you strew flowers keenly

You hand has picked a bunch of flowers from the branch

Garden, flower and grass do not allure us

Your face is as a flower garden

Accept this poem from Shafaq

That this flame is born out of my heart

(The same source, 194)

\section{CONCLUSION}

The main idea of Yazd poets like other Persian poets is description of spring and its beauties. Some of poets from Yazd describe the spring of nature like Vahshi Bafqi. Some are affected by conditions of time and social issues, including Farrokhi Yazdi who has a political view on the spring. By spring, he means freedom. Spring in Shafaq's poetry is the spring of revolution and describes Islamic revolution of Iran.

\section{References}

[1] Behjati, Mohammad Hosein, 1994, light rain; Islamic Guidance department of Ardakan, Tehran, Basir

[2] Hafiz, Khajeh Shams-al-din Mohammad, 2007, the complete poetical work, assisted by Khalil Khatib Rahbar, Sarvari publications, Tehran

[3] Farrokhi Yazdi, Mohammad, 2003, the sewn-lips poet, assisted by Gholamreza Mohammadi, Yazd

[4] Manouchehri Damghani, 1984, the complete poetical work, by Mohammad Dabir Siaghi, Zovvar bookstore, Tehran

[5] Molana, Jalaladdin Mohammad, 1986, Mathnavi, corrected by Nickleson, Molana publications, Tehran

[6] Nafisi, Saeid, 1962, living environment and Roudaki's conditions and poetry, Ibn-Sina Library publications, Tehran 